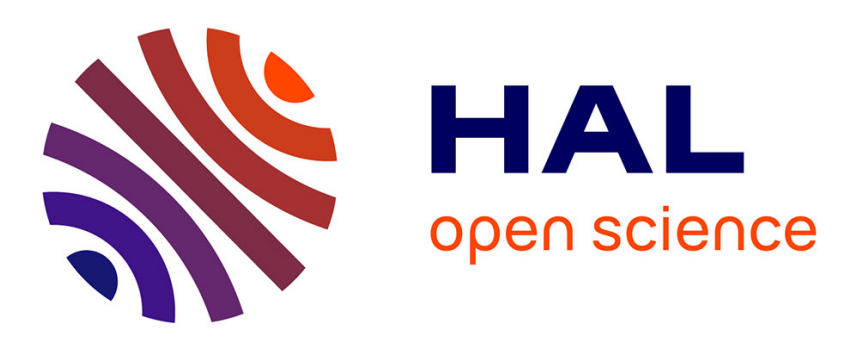

\title{
Technical Note: Is radiation important for the high amplitude variability of the MOC in the North Atlantic? \\ D. Nof, Lianbo Yu
}

\section{To cite this version:}

D. Nof, Lianbo Yu. Technical Note: Is radiation important for the high amplitude variability of the MOC in the North Atlantic?. Ocean Science Discussions, 2007, 4 (5), pp.699-707. hal-00298482

\section{HAL Id: hal-00298482 \\ https://hal.science/hal-00298482}

Submitted on 6 Sep 2007

HAL is a multi-disciplinary open access archive for the deposit and dissemination of scientific research documents, whether they are published or not. The documents may come from teaching and research institutions in France or abroad, or from public or private research centers.
L'archive ouverte pluridisciplinaire HAL, est destinée au dépôt et à la diffusion de documents scientifiques de niveau recherche, publiés ou non, émanant des établissements d'enseignement et de recherche français ou étrangers, des laboratoires publics ou privés. 
Radiation importance

D. Nof and L. Yu

\section{Technical Note: Is radiation important for the high amplitude variability of the MOC in the North Atlantic?}

D. Nof ${ }^{1,2}$ and L. $\mathrm{Yu}^{3}$

${ }^{1}$ Department of Oceanography, The Florida State University (FSU), Tallahassee, FL, USA

${ }^{2}$ The Geophysical Fluid Dynamics Institute (FSU), Tallahassee, FL, USA

${ }^{3}$ Department of Physical Oceanography, The Woods Hole Oceanographic Institution, Woods Hole, MA, USA

Received: 29 August 2007 - Accepted: 31 August 2007 - Published: 6 September 2007

Correspondence to: D. Nof (nof@ocean.fsu.edu)

\section{Title Page}

Abstract

Introduction

Conclusions

References

Tables

Figures

14

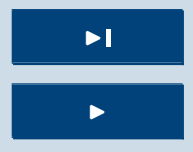

4

Back

Close

Full Screen / Esc

Printer-friendly Version

Interactive Discussion 


\section{Abstract}

Radiation is of fundamental importance to climate modeling and it is customary to assume that it is also important for the variability of North Atlantic Deep Water (NADW) formation and the meridional overturning cell (MOC). Numerous articles follow this

5 scenario and incorporate radiation into the calculation. Using relatively old heat-flux maps based on measurements taken in the nineteen sixties, Sandal and Nof (2007) recently suggested that, even though the radiation terms are of the same order as the other heat-flux terms, they are not important for the variability of the NADW and the MOC. They proposed that only sensible and latent heat fluxes are important for which supposedly correspond to turning convection on-and-off in the Atlantic.

Here, we place this suggestion on a firmer ground by presenting new and accurate up-to-date heat flux maps that also suggest that the radiation is of no major consequence to the NADW variability. Also, we attribute the relative importance of sensible 15 and latent heat fluxes and the contrasting negligible role of radiation to the fact that the latent and sensible heat fluxes are primarily proportional to the difference between the sea surface and the air temperature whereas the radiation is primarily proportional to the sea surface temperature, i.e., radiation is approximately independent of the atmospheric temperature. Due the small heat capacity ratio of air/water (1/4), the difference between the ocean temperature and the air temperature varies dramatically between the state of active and inactive MOC, whereas the ocean temperature by itself varies very modestly between a state of active and inactive convection.

\section{Introduction}

Given that for much of the world ocean, the radiation terms are of the same order 25 of magnitude as the sensible and latent heat-flux terms, one would intuitively expect the radiation to be important for climate change and climate modeling. Furthermore,
OSD

4, 699-707, 2007

Radiation importance

D. Nof and L. Yu

\section{Title Page}

Abstract Introduction

Conclusions References

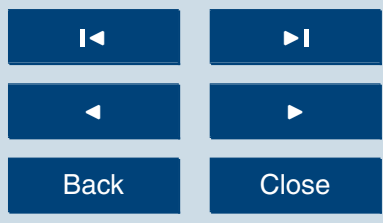

Full Screen / Esc

Printer-friendly Version

Interactive Discussion 
numerous calculations suggest that sea-ice is very important to climate change and this comes about through its effect on the radiation budget and the resulting albedo (see e.g., Gildor and Tziperman, 2003; Kaspi et al., 2004; Loving and Vallis, 2007). It is for these good reasons that radiation is usually taken to be an integral part of most 5 climate models (see e.g., Stouffer et al., 2006).

Understandably, radiation also plays an essential role in the interpretation of most of these climate models simulations. For instance, a potential cooling of Europe in response to a potential MOC slow down (see e.g., Bryden et al., 2005) is usually observed in most climate models and it is usually attributed to the importance of radiation. 10 An MOC slow down reduces the heat flux to the atmosphere and slightly lowers the sea surface temperature (SST). The argument then goes that, when the heat flux to the atmosphere is dominant by radiation (which is proportional to the SST but not the atmospheric temperature $T_{a}$ ), then a cooler atmosphere is intuitively expected to be the consequence of a reduced heat flux.

And yet, if one accepts the idea that the collapse of the meridional overturning cell $(\mathrm{MOC})$ is responsible for Heinrich events (i.e., events occurring during the last galciation when the mean atmospheric temperature in the northern hemisphere plunged almost $20^{\circ} \mathrm{C}$ for as long as 1000 years at a time, see e.g., Broecker, 1994; Clark et al., 2002), and, if one further accepts the notion that present calculations of the radiation terms are valid estimates of the present situation, then the conclusion that radiation is unimportant to the MOC is inevitable. In Fig. 1 (based on Yu and Weller, 2007, and Gupta et al., 2006) we show the three heat-flux components over the world ocean-radiation, sensible heat-flux and the latent heat-flux. Fig. 2 displays the standard deviation for the same variables. The important implications of these two figures
OSD

4, 699-707, 2007

Radiation importance

D. Nof and L. Yu

Title Page

Abstract Introduction

Conclusions References

Tables Figures

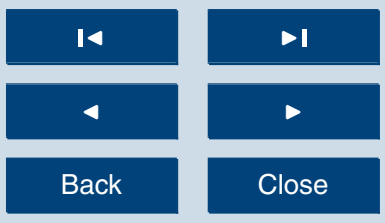

Full Screen / Esc

Printer-friendly Version

Interactive Discussion 


\section{Our analysis}

The importance of any heat-flux term to the long-term high-amplitude MOC variability can be decided on simply by using Fig. 1 to compare the heat flux terms in the Atlantic, where there is an MOC, to the same terms in the Pacific, where there is no MOC.

5 The results of such a comparison clearly points to the fact that the radiation terms are almost the same (for the same latitude) in the two oceans whereas the sensible and latent heat fluxes are very different in the two oceans. The same holds for the standard variation shown in Fig. 2.

Note that the dataset used in generating Figs. 1-2 covers only 21 years (1984-2004) 10 So that the shown standard deviation is associated with either the MOC, or the winddriven gyre circulation (such as the storm track variability) or both. Since our arguments rely on comparing the means in the two oceans (and the means correspond to a much longer time scale), the origin of this short-term variability is of no consequence to our arguments. This mean two oceans comparison shows that, evidently, sensible and 15 latent heat fluxes are important to the long-term variability of the MOC (i.e., turning it completely on-and-off which, according to paleoceanographic records, is $\sim O(100 \mathrm{yrs})$ ) but radiation is not. In what follows we will show that this is because the radiation is primarily dependent on the sea-surface temperature whereas the sensible and latent heat fluxes are proportional to the difference between the ocean and atmospheric 20 temperatures.

Radiation is proportional to the sea surface temperature (SST, indicated here by $T_{S}$ ) and is independent of both the salinity (Warren, 1983) and the air temperature $\left(T_{a}\right)$. Accordingly, the net upward longwave radiation from the ocean into the atmosphere is,

$$
Q_{L W}=\varepsilon_{S} \sigma T_{S}^{4}
$$

25 where $\varepsilon_{S}(=0.94)$ is the sea surface emissivity, and $\sigma=5.67 \times 10^{-8} \mathrm{Wm}^{-2} \mathrm{~K}^{-4}$ is the Stefan-Boltzmann constant. Because of the water relatively high heat capacity compared to air, $T_{S}$ does not change more than a few degrees as convection is turned

\section{OSD}

4, 699-707, 2007

Radiation importance

D. Nof and L. Yu

\section{Title Page}

Abstract Introduction

Conclusions References

Tables Figures

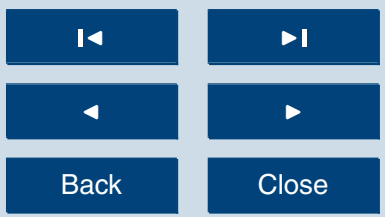

Full Screen / Esc

Printer-friendly Version

Interactive Discussion 
on-and-off so that $Q_{L W}$ remains roughly constant. Neglecting the effects of clouds, the first-order variation of the short wave radiation, $Q_{S W}$, can be approximated by the multiplication of the solar constant times the cosine of the solar zenith angle times $(1-\alpha)$, where $\alpha$ is the albedo. As in the long wave case, the direct effect of the atmospheric 5 temperature on $Q_{S W}$ is negligible (see e.g., Peixoto and Oort, 1992).

By sharp contrast, both the sensible and latent heat fluxes are strong functions of the atmospheric temperature $T_{a}$, which varies $10-20^{\circ} \mathrm{C}$ (due to the relatively small heat capacity of air) when convection is turned on-and-off (see e.g., Bard, 2002). Specifically, the sensible and latent heat fluxes from the ocean to the atmosphere are,

${ }_{10} F_{S}=\rho_{a} C_{p a} C_{S} U_{10}\left(T_{S}-T_{a}\right)$,

$F_{L}=\rho_{a} L_{e} C_{L} U_{10} q^{*}\left(1-R_{H}\right)+\rho_{a} C_{L} U_{10} R_{H} \frac{C_{p a}}{B e}\left(T_{S}-T_{a}\right)$

where $T_{S}$ is the convective oceanic temperature, $p_{w}$ and $p_{a}\left(\mathrm{~kg} \mathrm{~m}^{-3}\right)$ are the densities of water and air, $C_{p w}$ and $C_{p a}\left(\mathrm{~J} \mathrm{~kg}^{-10} \mathrm{~K}^{-1}\right)$ are the specific heat capacities of water and air, $F_{S}$ and $F_{L}\left(\mathrm{~W} \mathrm{~m}^{-2}\right)$ are the sensible and latent heat fluxes expressed in the 15 manner defined by Hartmann (1994), $C_{S}$ and $C_{L}$ are constants, $U_{10}\left(\mathrm{~m} \mathrm{~s}^{-1}\right)$ is the wind speed at $10 \mathrm{~m}$ above the surface, $q^{*}\left(\mathrm{~g} \mathrm{~kg}^{-1}\right)$ is saturation specific humidity of the air, $L_{e}\left(\mathrm{~J} \mathrm{~kg}^{-1}\right)$ is the latent heat of evaporation, $\mathrm{R}_{H}$ is relative humidity of the air, and $B e$ is the equilibrium Bowen ratio.

We see that the sensible, and much of the latent heat flux, are proportional to the 20 difference between the SST and the atmospheric temperature. Given that the air heat capacity is about $1 / 4$ of the water heat capacity, the air is subject to much larger temperature fluctuations than the ocean, simply because it easier to cool or heat the air than it is to cool or heat the water. The records for the last glaciaton period vividly display this trait (see, e.g., Bard 2002, his first figure). Hence, during times that the MOC varies will only vary about one fourth of the other terms variability. Whether variations that 703

\section{OSD}

4, 699-707, 2007

Radiation importance

D. Nof and L. Yu

\section{Title Page}

Abstract Introduction

Conclusions References

Tables Figures

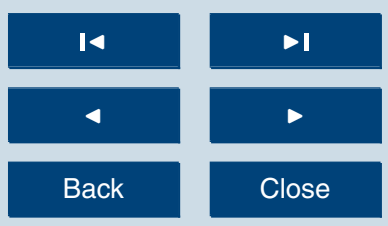

Full Screen / Esc

Printer-friendly Version

Interactive Discussion

EGU 
are $1 / 4$ of the largest terms are negligible or not is a judgment call, but the radiation maps displayed in Figs. 1, 2 clearly suggest that radiation is by far less important than sensible and latent heat fluxes.

Finally, we should probably re-iterate that, as stated in Sandal and Nof (2007), when 5 the heat flux is dominated by sensible and latent heat fluxes and the ocean is warmer than the atmosphere, a smaller heat flux implies a much warmer atmosphere and a slightly cooler ocean. This implies that a reduced MOC will warm, not cool Europe.

Acknowledgements. This study was supported by NSF grants: OCE-0545204 and ARC0453846, a NASA grant: NNX07AL97G, and the NOAA Office of Climate Observation and 10 the Office of Climate Change and Data Detection (under Grant NA17RJ1223).

\section{References}

Bard, E.: Climate shock: abrupt changes over millennial time scales. Physics Today, 55, 32-38, 2002.

Broecker, W. S.: Massive iceberg discharges as triggers from global climate change, Nature, 15 6, 183-190, 1994.

Bryden, H. L., Longworth, H. R., and Cunningham, S. A.. Slowing of the Atlantic meridional overturning circulation at $25^{\circ} \mathrm{N}$, Nature, 438, 655-657, 2005.

Clark, P. U., Pisias, N. G., Stocker, T. F., and Weaver, A. J.: The role of the thermohaline circulation in abrupt climate change, Nature, 415, 863-869, 2002.

20 Gildor, H. and Tziperman, E.: Sea-ice switches and abrupt climate change, Phil. Trans. R. Soc. Lond. A, 361, 1935-1944, 2003.

Gupta, S. K., Stackhouse Jr., P. W., Cox, S. J., Mikovitz, J. C., Zhang, T., and Hinkelman, L.: The NASA/GEWEX Surface Radiation Budget Dataset. American Geophysical Union, 22-26 May, Baltimore, Md., 2006.

25 Hartmann, D.: Global Physical Climatology, Academic Press, San Diego, CA, pp. 411, 1994.

Kaspi, Y., Sayag, R., and Tziperman, E.: A "triple sea-ice state" mechanism for the abrupt warming and synchronous ice sheet collapses during Heinrich events, Paleoceanography, 19(3), PA3004, doi:10.1029/2004PA001009, 2004.

\section{OSD}

4, 699-707, 2007

Radiation importance

D. Nof and L. Yu

\section{Title Page}

Abstract

Introduction

Conclusions

References

Tables

Figures

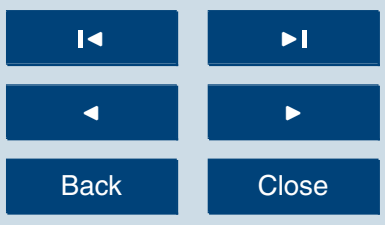

Full Screen / Esc

Printer-friendly Version

Interactive Discussion 
Loving, J. and Vallis, G.: Mechanism for climate variability during glacial and interglacial periods, Paleoceanography, 20, PA4024, doi:10.1029/2004PA001113, 2005

Peixoto, J. P. and Oort, A. H.: Physics of Climate. American Institute of Physics, 520 pp, 1992.

Sandal, C. and Nof, D.: A new analytical model for Heinrich events and climate instability, J. Phys. Oceanogr., in press, 2007.

Stouffer, R. J., Yin, J., Gregory, J. M., Dixon, K. W., Spelman, M. J., Hurlin, W., Weaver, A. J., Eby, M., Flato, G. M., Hausmi, H., Hu, A., Jungclaus, J. H., KAmenkovich, I. V., Leverman, A., Montoya, M., Murakami, S., Nawrath, S., Oka, A., Peltier, W. R., Robitaille, D. Y., Sokolov, A., Vettoretti, G., and Weber, S. L.: Investigating the Causes of the Repsonse of the Thermohaline Circulation to Past and Future Climate Changes, J. Climate, 19(8), 1365-1387, 2006.

Warren, B. A.: Why is no deep water formed in the North Pacific?, J. Mar. Res., 41, 327-347, 1983.

Yu, L. and Weller, R. A.: Objectively Analyzed Air-Sea Heat Fluxes for the Global Ice-Free Oceans (1981-2005), Bull. Am. Meteorol. Soc., 88, 527-539, 2007.

\section{OSD}

4, 699-707, 2007

Radiation importance

D. Nof and L. Yu

\section{Title Page}

Abstract Introduction

Conclusions

References

Tables

\section{Figures}

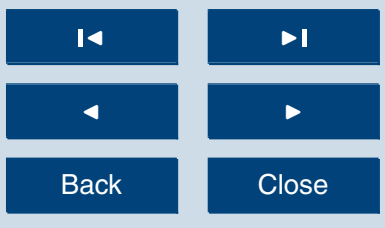

Full Screen / Esc

Printer-friendly Version

Interactive Discussion 
Net downward radiation
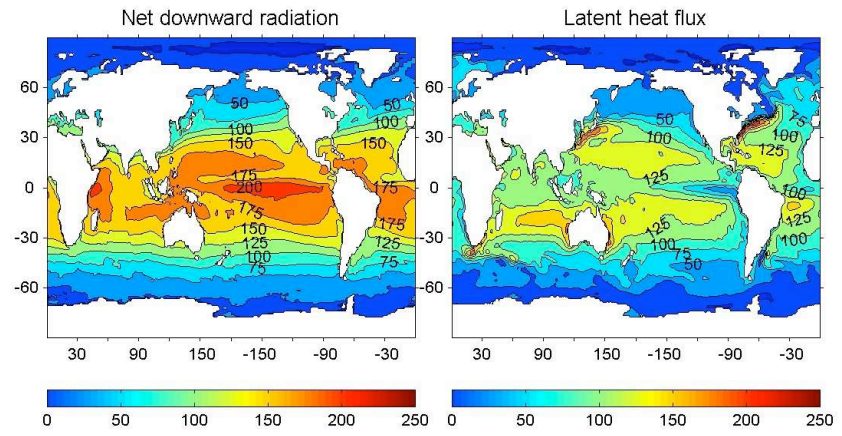

Sensible heat flux
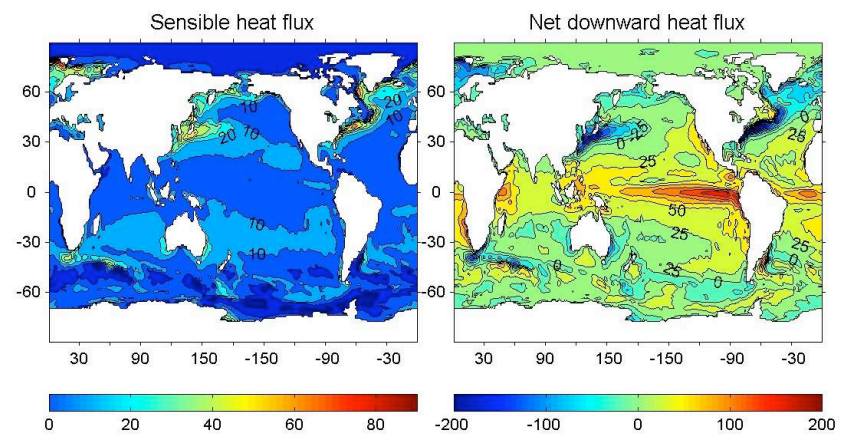

OSD

4, 699-707, 2007

Radiation importance

D. Nof and L. Yu

\section{Title Page}

Abstract

Introduction

Conclusions

References

Tables

\section{Figures}
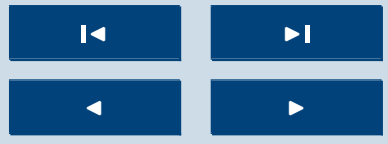

Back

Close

Full Screen / Esc

Printer-friendly Version

Interactive Discussion
Fig. 1. Modern annual average heat fluxes $\left(\mathrm{W} / \mathrm{m}^{2}\right)$ maps for the world ocean. Both the latent and the sensible heat fluxes show a dramatic difference between the North Atlantic (where there is convection) and the North Pacific (where there is no convection) indicating that both are important to NADW formation (with the latent being more important than the sensible). And yet, by sharp contrast, the (total) radiation maps (i.e., short-waves absorbed by the ocean minus long-wave radiation away from the ocean) show almost no difference between the two oceans indicating that it is not very important to the convection. This is because, even though the radiation terms are not small compared to the latent and sensible heat flux, they depend primarily on the SST, which, on a basin scale, does not vary much (compared to the atmosphere) between convective and non-convective states. 


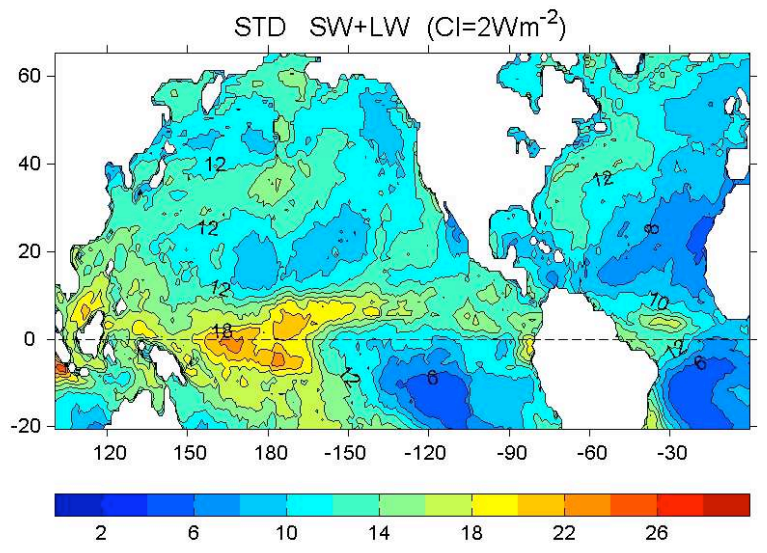

\section{OSD}

4, 699-707, 2007

Radiation importance

D. Nof and L. Yu

\section{Title Page}

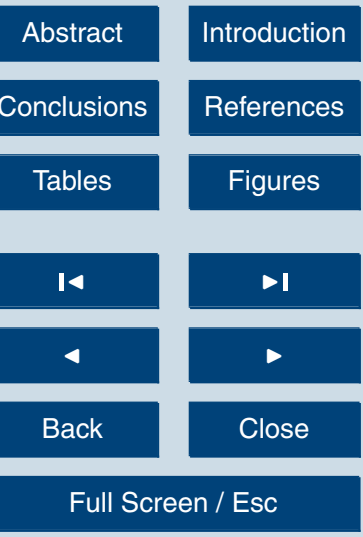

Printer-friendly Version

Interactive Discussion

\section{EGU}

heat flux (lower panel) for the north Atlantic and North Pacific As in the mean fluxes shown in Fig. 1, the difference between the sensible and latent heat fluxes in the two oceans is large, whereas the difference in the radiation is small. 